Article

\title{
A Proposal for the Account-Based Ticketing Application in Passenger Transport in the Slovak Republic: A Case Study
}

Eva Brumercikova *(D), Bibiana Bukova and Eva Nedeliakova

Faculty of Operation and Economics of Transport and Communications, University of Zilina, 01026 Zilina,

Slovakia; bibiana.bukova@fpedas.uniza.sk (B.B.); eva.nedeliakova@fpedas.uniza.sk (E.N.)

* Correspondence: eva.brumercikova@fpedas.uniza.sk; Tel.: +421-41-513-3417

Received: 5 June 2020; Accepted: 23 June 2020; Published: 8 July 2020

\begin{abstract}
From the point of view of the national economy, the development of a transport sector is a key process which relies on many other industries. Therefore, it is inevitable to coordinate related activities and to develop the transport sector effectively, and significant synergies in relation to other sectors could be generated. This article deals with the issue of public passenger transport and its greater attractiveness through the account-based ticketing (ABT) technology application in the process of passenger handling. The article contains a review of the current literature on the subject, using both completed and partially completed studies. It presents the case of study of account-based ticketing in the Slovak Republic. ABT technology has already been introduced in many countries, for example, in the Netherlands in 2019, and in Singapore.
\end{abstract}

Keywords: account-based ticketing; passenger transport; development trend

\section{Introduction}

Public passenger transport in the Slovak Republic is an area of transport which does not currently fulfil economic, social, environmental and transport policy goals. It is necessary to mention that one of the fundamental problems of passenger transport is the long-term unfavourable development of transport work division, which favours individual (non-public) transport [1-3]. Figure 1 presents a share of public and non-public passenger transport within the transport performance in the Slovak Republic. The data for the analysis were obtained from statistical data of the Statistical Office of the Slovak Republic [4].

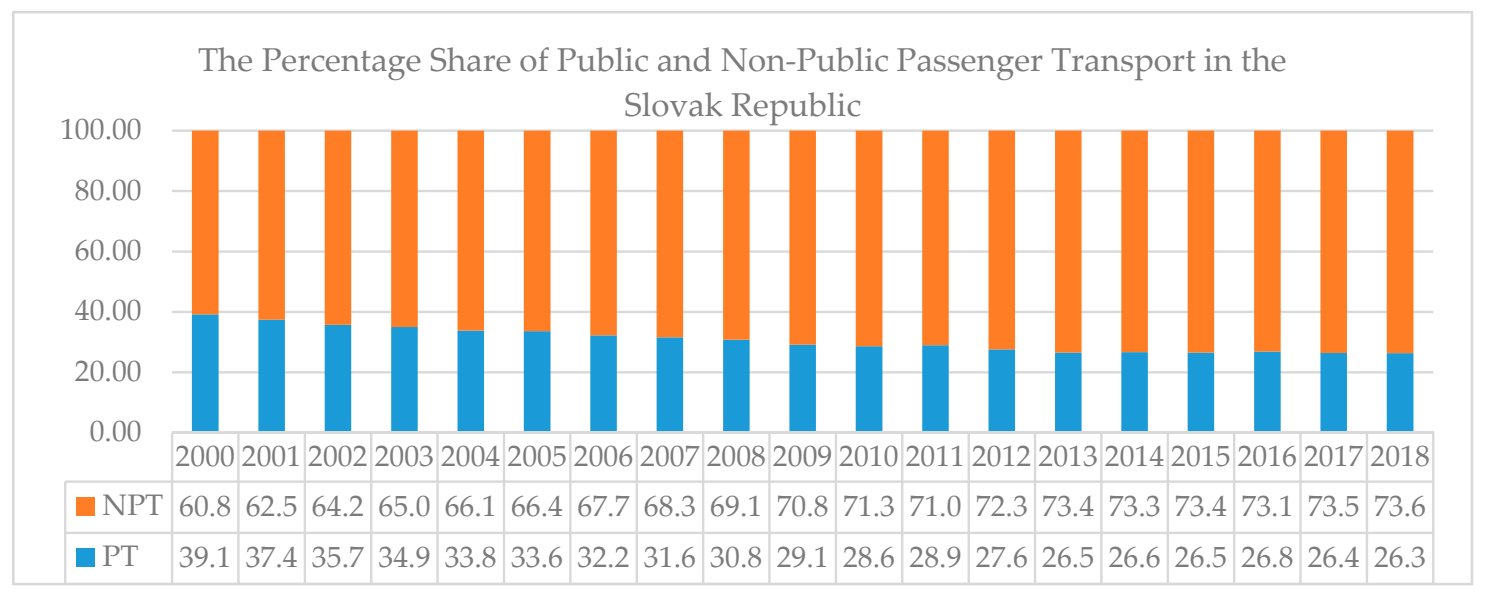

Figure 1. The percentage share of public and non-public passenger transport in the Slovak Republic. 
Figure 1 makes a clear case that during 2000-2018 the percentage share of public passenger transport decreased from $34.05 \%$ to $28.53 \%$. Starting in 2014, there was a slight increase related to the launch of free rail passenger transport for students and seniors. Despite this measure of the state, however, public passenger transport has never increased beyond $40 \%$.

\section{A Prediction of the Development Trend of Public Passenger Transport}

A prediction of the development trend of public passenger transport was performed using regression equations. To verify the impact (i.e., the dependency and independency of selected factors on the number of carried passengers by means of public passenger transport) a regression model was used. This econometric model works based on a system of equations which uses prerequisites to draw the models up, such as data files obtained from statistical offices and industrial databases. This econometric model expresses quantitative dependencies among individual quantities. The studied phenomena had a quantitative dimension in econometric models when mutual relations of quantities play the role of variable quantities in the equations $[5,6]$.

Dependencies among individual quantities are expressed via equations in econometric models. Each equation explains a condition or a development of one variable being explained at a time. As long as $n$ variables are explained, $n$ equations are formed. Relations among variables are expressed via regression equations in econometric equations, resulting in a regression equation that contains a variable being explained (usually expressed with a symbol $y$ ), whereas some explaining variables (e.g., $\left.x_{1}, x_{2} \ldots x_{n}\right)$ and some parameters (coefficients) of the regression equation (e.g., $b_{0}$ ) are bound to one of explaining quantities. Some parameters refer to explaining quantities (e.g., $b_{1} \ldots m$ ), a quantity of a random component, or an error of observation (e.g., $u$ ). If the parameters of $b_{0}$ and $b_{1}$ variables take numerical values, then the equation $y=b_{0}+b_{1} x$ is a regression line of the $y$ variable with regard to the $x$ variable. In this case it is an expression of the $y$ variable using a linear relation, and such a regression is called a linear regression [5]. The regression model and regression equations are explained in more detail in the 'The Regression and Correlation Analysis of Carried Person by Means of Public Passenger Transport of the Slovak Republic' [7], in which partial results of the research are published. The article also includes other factors that assume dependency on the number of carried passengers by means of public passenger transport in the Slovak Republic (SR).

The following dependent variables have been chosen for the sake of calculations needed in the article:

- The number of inhabitants of the Slovak Republic (SR) and the development trend of the number of inhabitants in the SR set by the Scientific Research Centre of the SR;

- The average nominal wage in the SR and the development trend of the average wage calculated on the base of statistical methods.

Based on available statistical data, and the forecast of the development of the SR population by 2035 , it is possible to estimate the trend of development of public passenger transport in the SR. The trend of development of the SR population (based on the research conducted by the Scientific Research Centre [8]) is presented in Table 1. This forecast was updated by the Scientific Research Centre in 2018.

The regression equation was determined employing a linear regression model. For the sake of accuracy and making the calculation simpler both, the number of inhabitants and the number of passengers carried by public passenger transport were given in millions. Then, a simple linear regression model of dependency of carried passengers on the number of inhabitants was realised (Figure 2).

In the forecast of the development of the number of passengers carried by public passenger transport in the SR by 2035 the regression equation $y=-4324.7 x+24,210$ was used (Figure 2). The dependency was verified with the division of Fisher. The dependency itself makes a clear case that the number of passengers decreases with an increasing number of inhabitants; however, the 
forecasts of the Scientific Research Centre of the SR predict a decreasing number of inhabitants in the SR. This implies that the number of carried passengers is inversely proportional to the number of inhabitants in the SR. If the forecast came out of the equation above, then the number of passengers carried by public passenger transport would be 536.086 million passengers in 2030, and 723 million passengers would take public passenger transport in 2035. Figure 3 presents a comparison of the number of persons carried by public passenger transport according to statistical data by 2018 while applying the regression equation from 2000 to 2035.

Table 1. The number of inhabitants of the Slovak Republic (SR) and development trend of the number of inhabitants of the Slovak Republic set by Scientific Research Centre of the SR [8].

\begin{tabular}{cccccccc}
\hline Year & $\begin{array}{c}\text { The Number } \\
\text { of Inhabitants } \\
\text { in the SR }\end{array}$ & Year & $\begin{array}{c}\text { The Number } \\
\text { of Inhabitants } \\
\text { in the SR }\end{array}$ & Year & $\begin{array}{c}\text { The Number } \\
\text { of Inhabitants } \\
\text { in the SR }\end{array}$ & Year & $\begin{array}{c}\text { The Number } \\
\text { of Inhabitants } \\
\text { in the SR }\end{array}$ \\
\hline 2000 & $5,402,547$ & 2010 & $5,435,273$ & 2020 & $5,464,722$ & 2030 & $5,474,117$ \\
2001 & $5,378,951$ & 2011 & $5,404,322$ & 2021 & $5,471,187$ & 2031 & $5,467,377$ \\
2002 & $5,379,161$ & 2012 & $5,410,836$ & 2022 & $5,476,815$ & 2032 & $5,459,533$ \\
2003 & $5,380,053$ & 2013 & $5,415,949$ & 2023 & $5,481,561$ & 2033 & $5,450,737$ \\
2004 & $5,384,822$ & 2014 & $5,421,349$ & 2024 & $5,485,028$ & 2034 & $5,441,137$ \\
2005 & $5,389,180$ & 2015 & $5,426,252$ & 2025 & $5,487,064$ & 2035 & $5,430,897$ \\
2006 & $5,393,637$ & 2016 & $5,435,343$ & 2026 & $5,487,548$ & & \\
2007 & $5,400,998$ & 2017 & $5,443,120$ & 2027 & $5,486,426$ & & \\
2008 & $5,412,254$ & 2018 & $5,450,421$ & 2028 & $5,483,756$ & & \\
2009 & $5,424,925$ & 2019 & $5,457,873$ & 2029 & $5,479,626$ & & \\
\hline
\end{tabular}

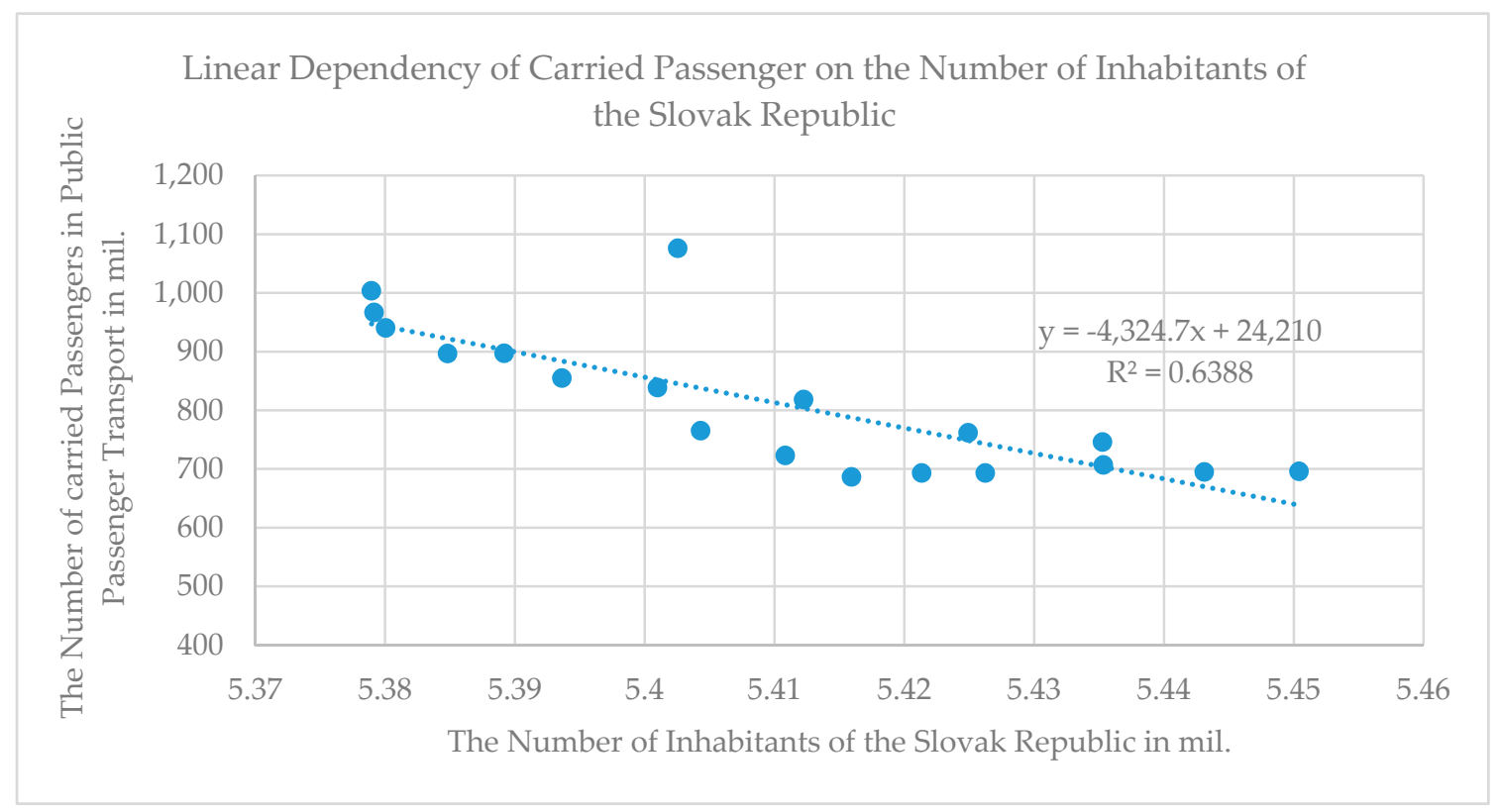

Figure 2. Linear dependency of passengers carried by public passenger transport on the number of inhabitants in the SR.

To verify or disprove the forecast above, the dependency of carried passengers on the average wage was chosen. The development of the average wage in the SR is presented in Table 2.

The regression equation has been determined through a linear regression model, and for the sake of accuracy and making the calculation simpler, the number of passengers carried by public passenger transport is given in millions. Then, a simple linear regression model of dependency of carried passengers on the average nominal wage in the SR is realised. 


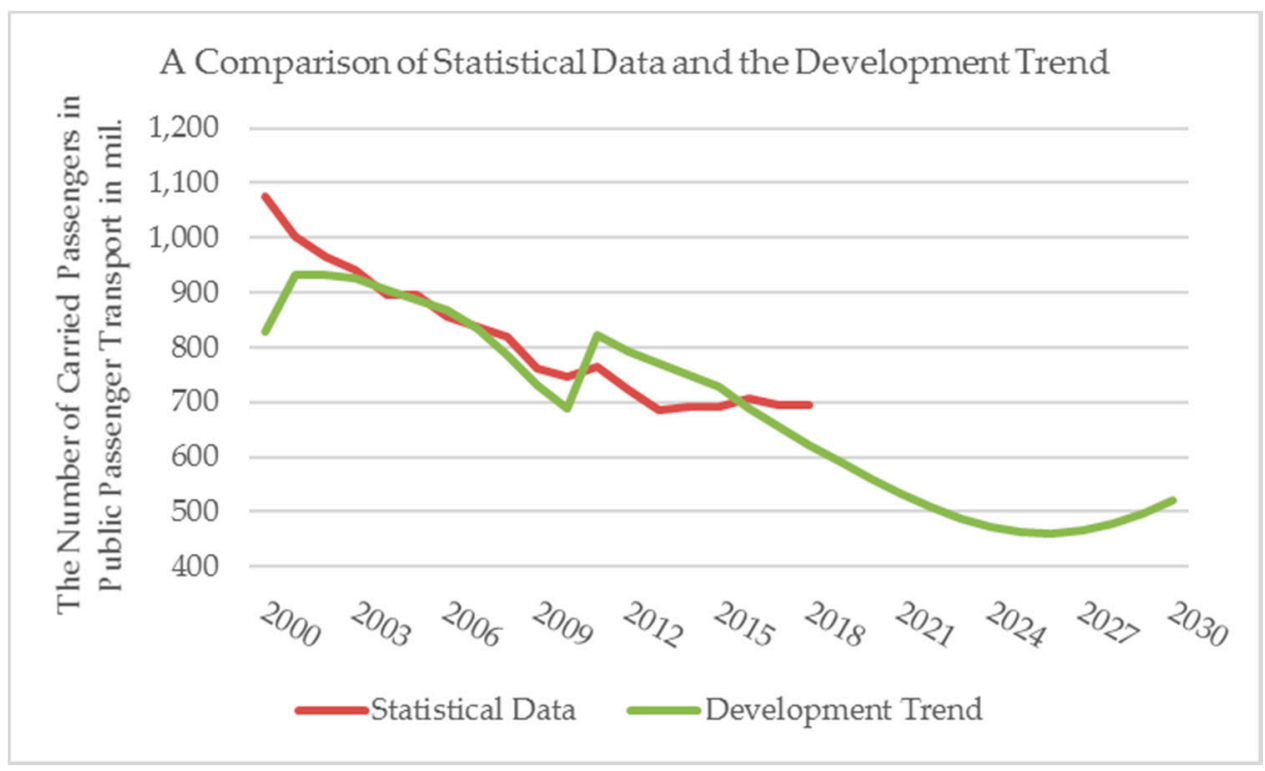

Figure 3. A comparison of statistical data and the development trend according to the linear dependency of persons carried by public passenger transport (million).

Table 2. The development of the average wage in the SR [4].

\begin{tabular}{|c|c|c|c|c|c|c|c|}
\hline Year & $\begin{array}{l}\text { The Average } \\
\text { Nominal Wage } \\
\text { in the SR (€) }\end{array}$ & Year & $\begin{array}{l}\text { The Average } \\
\text { Nominal Wage } \\
\text { in the SR (€) }\end{array}$ & Year & $\begin{array}{l}\text { The Average } \\
\text { Nominal Wage } \\
\text { in the SR (€) }\end{array}$ & Year & $\begin{array}{l}\text { The Average } \\
\text { Nominal Wage } \\
\text { in the SR }(€)\end{array}$ \\
\hline 2000 & 379.41 & 2005 & 573.39 & 2010 & 769.00 & 2015 & 883.00 \\
\hline 2001 & 410.44 & 2006 & 622.75 & 2011 & 786.00 & 2016 & 912.00 \\
\hline 2002 & 448.48 & 2007 & 668.72 & 2012 & 805.00 & 2017 & 954.00 \\
\hline 2003 & 476.83 & 2008 & 723.03 & 2013 & 824.00 & 2018 & 1013.00 \\
\hline 2004 & 525.29 & 2009 & 744.00 & 2014 & 858.00 & 2019 & 1092.00 \\
\hline
\end{tabular}

In the forecast of the development of the number of passengers carried by public passenger transport in the SR by 2030 the regression equation $y=-0.6092 x+1242.3$ was used (Figure 4 ). The dependency was verified with the division of Fisher. The dependency itself makes a clear case that the number of passengers decreases with an increasing average nominal wage in the SR. It may be stated again that it is an inverse proportional dependency. The values of the average nominal wage for the years 2020-2021 were determined under the Stability Programme of Slovakia [8], and the values of the average nominal wage by 2030 were determined by the convergence of the Slovak economy to developed economies [9]. According to the linear regression, the number of passengers carried by public passenger transport would be 327.8908 million in 2025 and only 51.314 million passengers in 2030. Figure 5 presents a comparison of the number of passengers carried by public passenger transport according to statistical data by 2018 while applying the regression equation from 2000 to 2030 .

The trend of development of the number of carried persons in the case of a linear dependency on the average nominal monthly wage was determined by 2030; the reason for which was that the indicator of the average monthly wage is too variable and hard to predict. In this dependency, the number of carried passengers decreases rapidly which, however, is not real from the perspective of the transport policy. For the sake of comparison Figure 6 presents predictions of the number of inhabitants and the average nominal wage in the SR. 


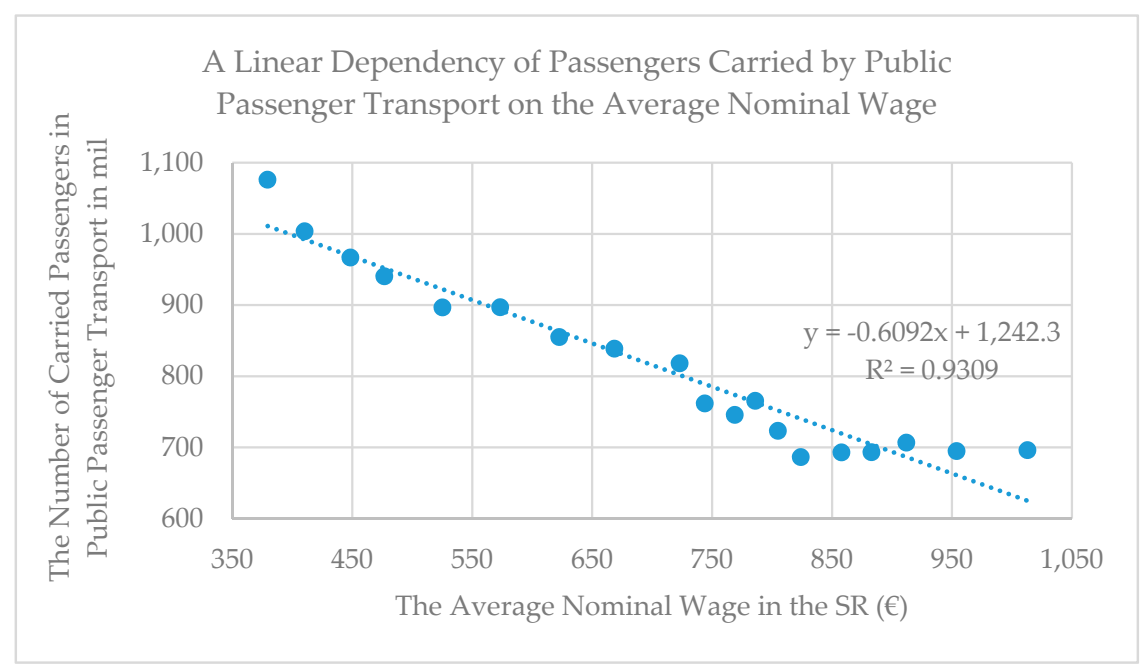

Figure 4. A linear dependency of passengers carried by public passenger transport on the average nominal wage.

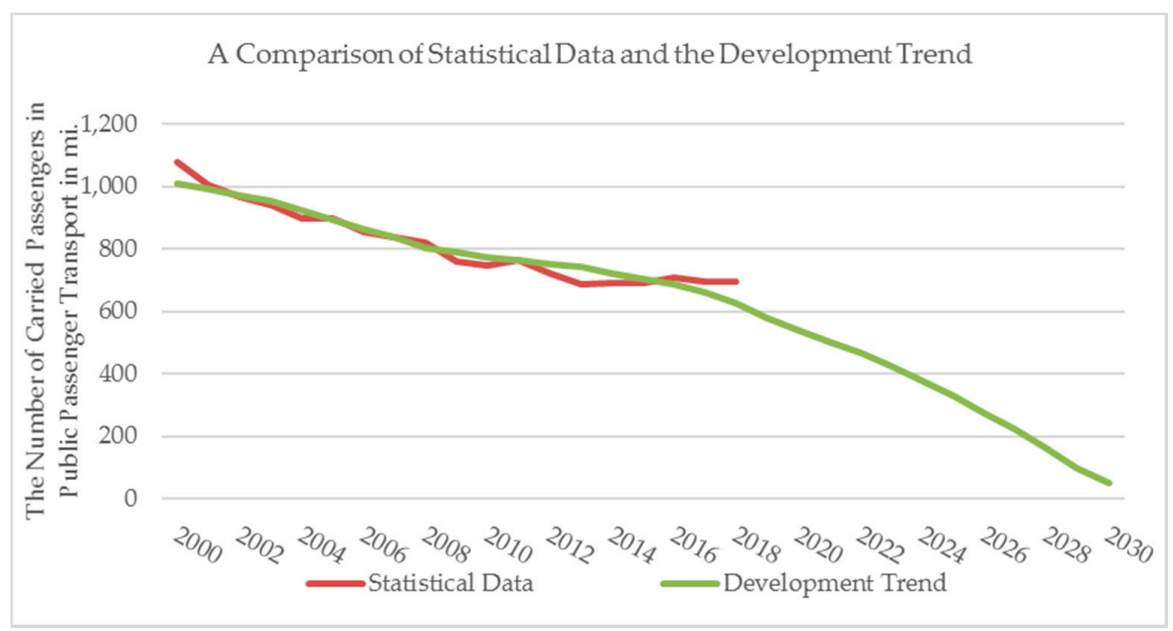

Figure 5. A comparison of statistical data and the development trend according to the linear dependency of persons carried by public passenger transport (million).

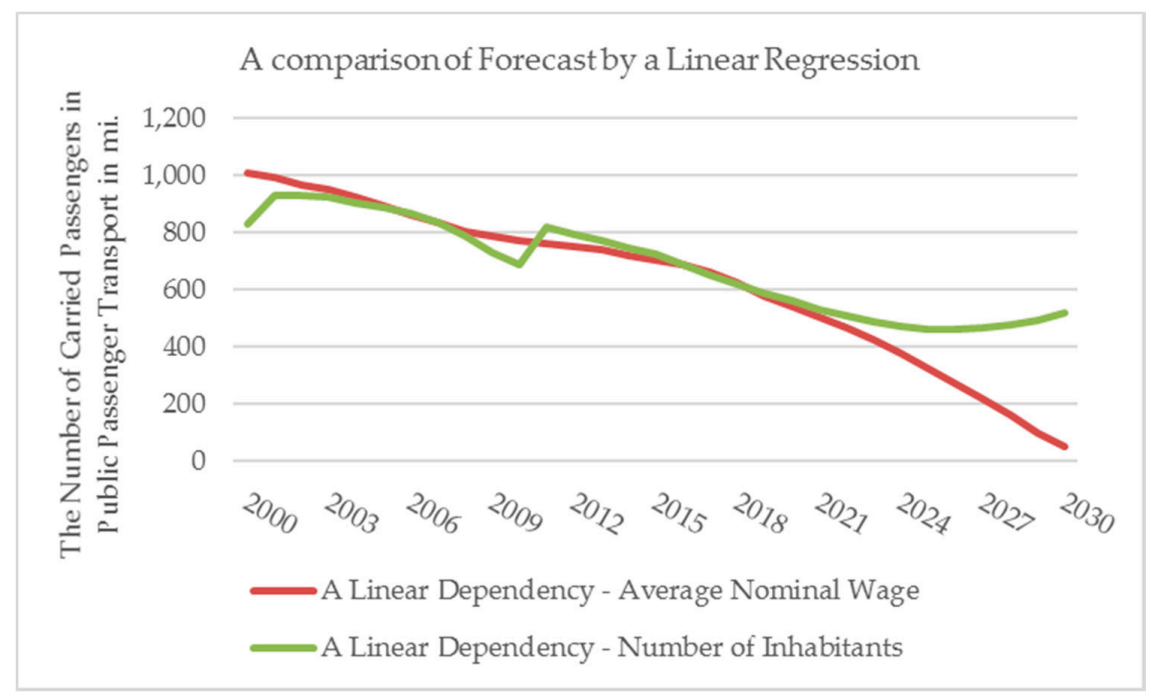

Figure 6. A comparison of forecasts by linear regression. 
The analyses above show a decreasing tendency of passengers carried by public passenger transport. Mainly based on the significant dependency of carried passengers on the average monthly wage and minimum wage [10] it can be assumed that, along with an increasing average monthly wage and an increasing minimum wage, a decline in the inhabitants' interest in public passenger transport can be anticipated. Thus, it is necessary to improve the quality of services provided by public passenger transport so the inhabitants (potential customers) are motivated to utilise public passenger transport. One of the options to increase the interest of inhabitants in public passenger transport is the option to utilise new, progressive and innovative methods of passenger handling. As part of the research, a multi-criteria method was used to evaluate three progressive methods of passenger handling, namely near-field communication (NFC), Europay/MasterCard/Visa (EMV) and account-based ticketing (ABT) technology. The technologies were evaluated using the total utility method, the weighted sum approach (WSA) method and Technique for Order Preference by Similarity to Ideal Solution (TOPSIS) method. Table 3 presents mutual comparison of result of result of Multi-Criterial Decision. The scientific paper presents the results of the multi-criteria evaluation [11]. An optimal variant would be one which would get the value of one in the resulting evaluation. This variant would achieve the best values out of the available evaluation scale in all evaluation criteria. The result of the entire calculation is thus mainly affected with values of the input criteria matrix and the vectors of individual criteria weights.

Table 3. Mutual comparison of results of multi-criterial decision-making methods [11].

\begin{tabular}{cccc}
\hline Technology & Total Utility Method & WSA Method & TOPSIS Method \\
\hline NFC & 0.8628571 & 0.171429 & 0.4622066 \\
EMV & 0.9809524 & 0.941176 & 0.6480883 \\
ABT & 0.9171429 & 0.304045 & $0.6442968^{1}$ \\
\hline
\end{tabular}

\footnotetext{
${ }^{1}$ Abbreviations: WSA: Weighted Sum an Approach; TOPSIS: Technique for Order Preference by Similarity to Ideal Solution; NFC: Near-Field Communication; EMV: Europay/MasterCard/Visa; ABT: Account-Based Ticketing.
}

The table data imply that multi-criteria decision-making methods (total utility, WSA, TOPSIS) match in the order of individual variants. EMV technology has been evaluated as the most appropriate variant of passenger handling in public passenger transport; it has reached the highest values in the input matrix, too. The technology has the highest score with regard to compatibility, safety, universality, speed and versatility. EMV technology has already achieved some results in practice. Inhabitants have gotten used to a cashless payment system, as proven by statistical data of the Slovak Banking Association. It states that there were 5,228,729 payment cards issued by 31 December 2019. However, it is necessary to point out that public transport is also utilised by children who do not hold any payment cards. From this point of view, the ABT technology might rather be accepted; passengers would register using their electronic ID (eID) card, which should be owned by all citizens of the Slovak Republic including children from their birth by the end of the year 2021 [11].

A proposal for the implementation of NFC technology in public passenger transport was published in the article 'Proposal for Using the NFC Technology in Regional Passenger Transport in the Slovak Republic' [12]. A conventional approach to e-ticketing (e.g., NFC technology) is oriented towards contactless chip cards or mobile phones with an active NFC chip. During verification, a validator checks if the card is genuine, personalised and if it can be authenticated. The main disadvantage of technologies oriented towards cards is the fact that terminals require a certain level of intelligence, and the data have to be synchronised and managed. This results in limited flexibility and a complex synchronisation of the system. This article will present the option to introduce ABT technology which is more innovative than NFC technology. 


\section{A Proposal for the Utilisation of ABT Technology in Public Passenger Transport in the SR}

Account-based ticketing technology is based on two fundamental principles, as follows:

- Transport law and contracts are based on an account on a central server, not on a card or another medium;

- The software and logic for the fare calculation are located in a back-office, not in validators, terminals, or vending machines [13].

This means that ABT technology offers carriers the option to move the software for the fare calculation from validators to the back-office where the passenger's account occurs. The back-office then aggregates transactions and applies algorithms to calculate the fare and charges the fare from the applicable bank account. It can be stated that the implementation of ABT technology allows for a so-called AFC (Automatic Fare Collection) system of electronic tickets, known as e-ticketing [14]. AFC systems are capable of calculating the best price for a passenger on the basis of the travel distance, travel history or discounts offered by individual carriers. The passenger's account in the back-office should be available online; this way all changes of the account are valid instantly which removes a need for a physical sales and distribution infrastructure. Thanks to the back-office it is possible to apply multiple forms of a payment model during the implementation, such as direct invoicing to the bank account (like in case of invoicing for a mobile phone) or linking of accounts (e.g., family members may share one account) [15].

One of the advantages of the account-based system is the ability to create various attractive additional products. Payment systems based on accounts may link reasonably secured "travel rights", or so-called "tokens" to one account. This may allow for the introduction of new innovative models of interconnected types of transport, such as park-n-ride, when even the licence number of a vehicle may be linked to an account which enables integrated parking and incentive discounts [16].

\subsection{The Implementation of ABT Technology in Public Passenger Transport with Payment Cards of Passengers}

The first proposal for the implementation of ABT technology in public passenger transport would be its combination with EMV technology. In the case of implementing this proposal, an open payment would be made possible for the tickets selling. A payment card would be used as an identifier (medium) of a passenger. The main advantage of this proposal is as follows: payment cards are certified and there is virtual interoperability among payment cards and terminals guaranteed. Both, payment cards and terminals are subject to certification which includes mutual testing: payment cards are tested on reference terminals, and reference terminals are tested on cards. For EMV technology a terminal must be certified by Payment Card Industry, Data Secure Standard (PCI DSS) standard, an international security standard which aims to prevent leakage of sensitive data about holders of payment cards and other electronic payment tools. The observance of PCI DSS standards requires all subjects who receive, collect, transfer and process or store data about payment cards' holders to secure permanent protection of sensitive information.

A big advantage of using EMV technology while implementing ABT technology into public passenger transport is that they do not require creating any purposefully blocked accounts since they are linked to existing accounts of their owners $[17,18]$.

When ABT technology is used in combination with EMV technology in public passenger transport, a registration of the payment card in a clearing centre (web interface) is necessary. The cardholder must register to get access to the web interface; an e-mail which serves as a user's password, and a payment card are needed for the registration. The cardholder makes a fictitious payment of $1 €$ during the registration which, however, will not be charged. This fictitious payment is made due to the verification of the payment card's validity. Multiple cards can be assigned to one e-mail account then. If a passenger needs a tax document, they can print it for each e-ticket via the web interface. The transport system must be designed with regard to the information safety and personal data protection. The communication with a bank is encrypted with a 3D secure element. The back-office 
itself does not collect, process or store any personal data of a passenger. No full name of a passenger or a bank card number can be kept in the system. The system does not work with the full number of the payment card, but it works with its encrypted form, a so-called token; the key to deciphering it is owned by the bank so the back-office of the public passenger transport system does not know what numbers of payment cards are in the system. For example, the back-office has only the first six or last four ciphers of the payment card number available which can be used in case of complaints for instance [19-22].

This proposal assumes to apply a check-in/check-out type of validation in validators placed in vehicles. During the validation with a payment card, the passenger checks in and checks out and the data on transport (the kind of transport, the kind of a transport means, the carrier) will be stored in the passenger's account in the back-office. When the transport is completed, the passenger checks out; at this moment the fare is not calculated and charged from their account like in case of NFC technology, but it will be stored in a database of the passenger's transports on that day in the clearing centre. At the end of the day, the software calculates the optimal fare for the passenger on the basis of carriers' tariffs that are stored in the back-office of the clearing centre. Finally, the software creates payment orders for the passenger's bank, and the bank will transfer the fare to individual carriers.

In case the passenger's payment card expires, it will be deleted from the back-office. When the passenger gets a new payment card, it will be registered in the back-office of the clearing centre and paired with the passenger's account, or a new account will be created in the database of the back-office. Provided the passenger has a claim to get any discounts at the carriers, they will receive them during the opening of the account.

In case of a ticket inspection on a transport, the passenger will prove themselves with a payment card, and the inspector will have a list of checked-in cards available. They will hold the passenger's payment card to the reading machine, and it will evaluate if the passenger has been checked in the system of passenger handling. In case the passenger has not been checked in there are two possible solutions. In the first case, the payment card will be blocked in the back-office and it will be unblocked only after paying a fine for not observing the transport regulations. The second option is that the reading machine will serve as a payment terminal simultaneously and the passenger will be able to pay the fine with their own payment card. In that case, the payment card will not be blocked, however, the fine for not observing the transport regulations of the carrier will be recorded in the passenger's account in the database. The chart of utilising this alternative of implementation in public passenger transport is represented in Figure 7.

The disadvantage of this system is as follows: not all passengers will be payment card holders. Mainly children under 15 should be equipped with separate contactless cards they would use to check in and out from the system. There also exists the option to link contactless cards of children with a payment card of legal representatives of the child. 


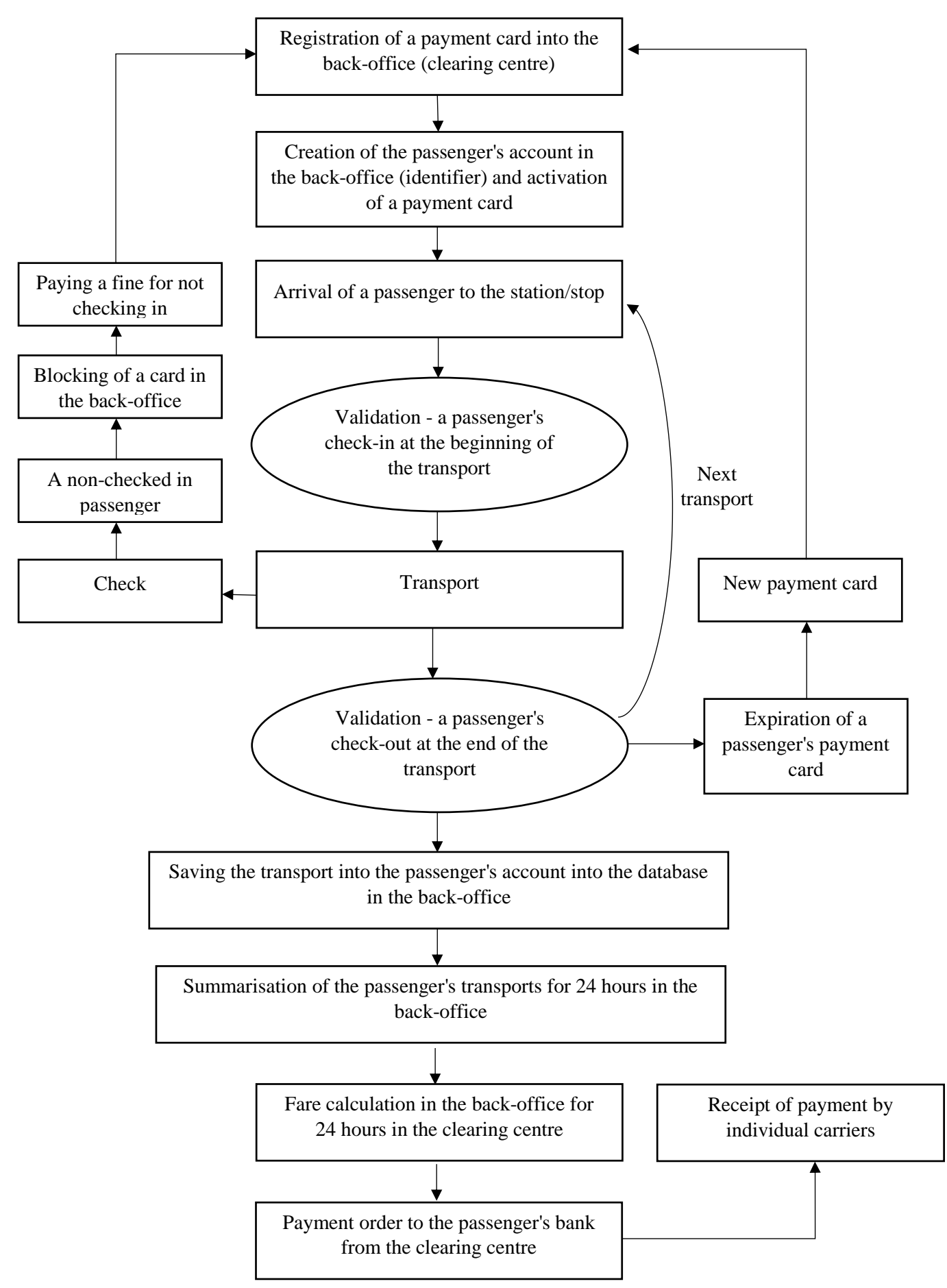

Figure 7. A model diagram of using ABT technology when combined with EMV technology in public passenger transport.

\subsection{The Implementation of ABT Technology in Public Passenger Transport with Electronic ID Cards}

The second proposal for the application of ABT technology in public passenger transport is the utilisation of an electronic ID card, a so-called eID, instead of a payment card for identification. According to a proposal for a new act in the SR, children under 15 should receive cards for checking in electronic services for the sake of their identification. 'This card should be visually identical to the ID card, however, it will not contain a photograph of its holder, since it will be issued ex officio.' Under Act No. 224/2006 Coll., an electronic ID card is secured with a safety code. Along with the ID card, the 
safety code serves for the confirmation of the holder's identity in electronic communication with information systems of public authorities as well as with other physical and legal entities. The safety personal code is a combination of at least six and no more than ten numbers.

The fact above allows for the application of the second proposal and allows for using an electronic ID card for identification in the system during validation which removes the need to issue separate contactless cards for passengers [23,24]. Figure 8 represents a model of a possible application of ABT technology into public passenger transport with an eID card.

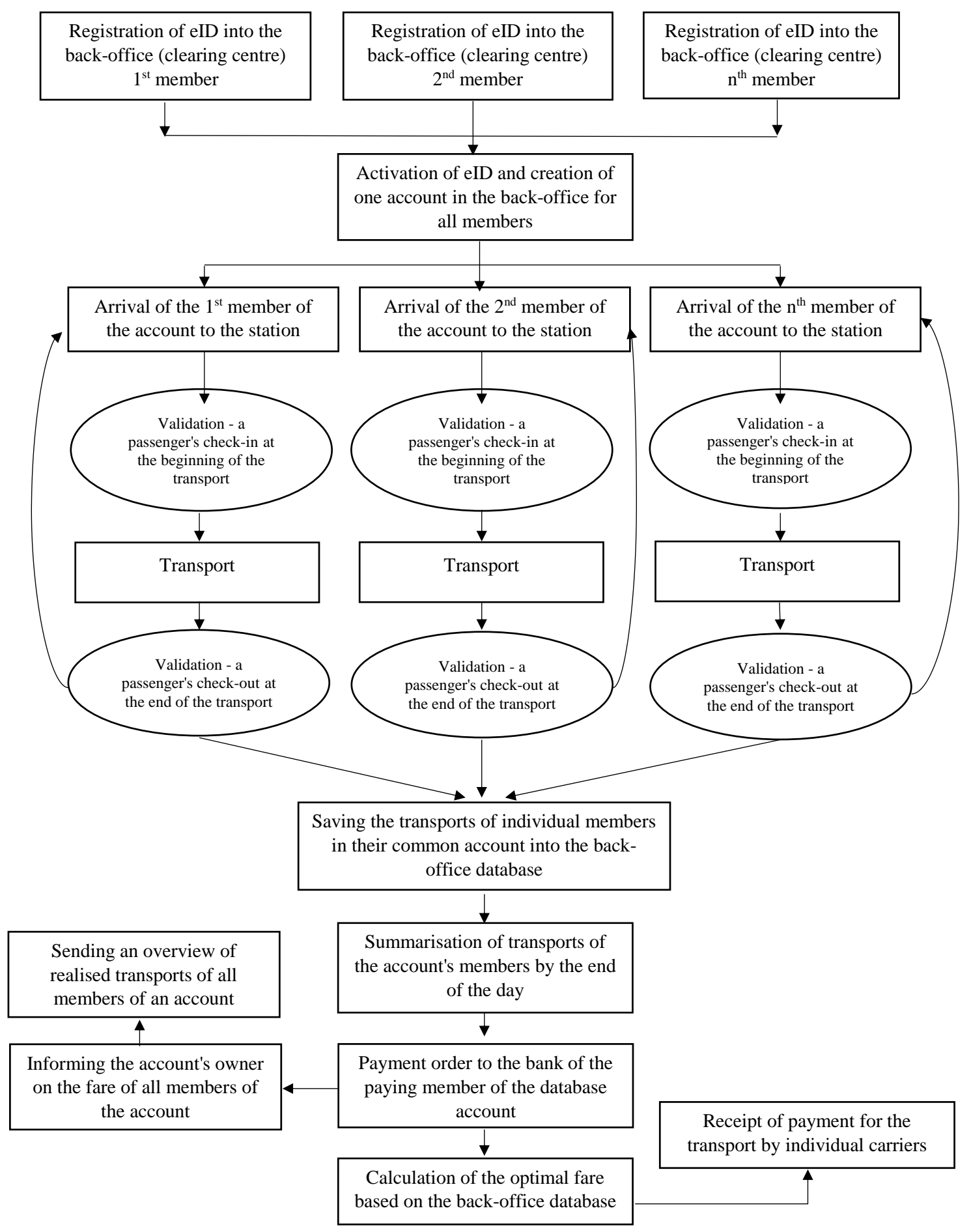

Figure 8. A model diagram of a possible application of ABT technology into public passenger transport with an electronic ID (eID) card. 
Figure 8 implies that thanks to electronic ID cards, which are sufficiently protected with a personal safety code, the disadvantage of the first proposal (not every passenger owns a payment card) is removed, and the necessity to issue contactless cards to all prospects is removed as well. The advantage of this proposal lies in the option to connect more electronic ID cards into one account in the back-office database (family accounts). The first step is the registration of electronic ID cards into the back-office database and at the same time the creation of a single account for all members of a group (e.g., family, or employees of one employer). The following procedure is the same as in the previous proposal when individual members of an account utilise services of individual carriers when they check in and out of the system as needed. When compared to NFC technology, individual transports are saved in the back-office database, thus they are not charged instantly. The accounting may be established per the agreement (i.e., it may be on a daily, weekly, biweekly or monthly basis). From the conversations with carriers during the researches in 2018-2019, an optimal accounting is the daily method, so passengers do not utilise their services "on credit". By the end of the day, the software summarises all transports of members of a given account and calculates the optimal fare based on tariffs which are part of the software. In all analyses EMV technology has been determined as the optimal technology for passenger handling; also in this case, it is possible that based on the summary and fare calculation the services of the clearing centre may be utilised in a way that would submit a payment order to the bank of the paying member of the database account.

Passengers will be informed on individual transports of members of the account; the summary data will be sent to the e-mail address in agreed times.

\section{Conclusions}

Based on the analyses realised during the research and based on the transport strategy for public passenger transport, it is required to make public passenger transport in the SR more appealing. The implementation of the progressive technology for passenger handling-in this article it is namely the implementation of ABT technology with the utilisation of an electronic ID card and EMV technology - has been shown as the most progressive one with a high potential for the future also concerning world trends in the area.

This article presents two proposals for the implementation of ABT technology. The first proposal lies in the implementation of ABT technology in public passenger transport with payment cards of passengers (i.e., a combination with EMV technology). This proposal has been worked out using data from the Slovak Banking Association according to which almost 5.5 million payment cards were issued in the SR by the end of the year 2018; from a statistics perspective, this means saturation of one card per one inhabitant of the Slovak Republic. For this proposal, the registration of a payment card into a so-called back-office and clearing centre is required. Furthermore, a passenger will use it as an identifier for the validation at the beginning and the end of their transport. Individual transports of the passenger will be saved in the account in the back-office; at the end of the day, the software will calculate the optimal fare for the passenger based on tariffs of individual carriers whose services the passenger has utilised. The task of the clearing centre will be to create payment orders for the passenger's bank, and the bank will transfer the fare (i.e., proceeds for the transport to individual carriers). The disadvantage of this proposal is that each passenger would have to be an owner of a payment card which is, however, not true.

Due to the disadvantage of the first proposal, the second alternative of the ABT technology application with the utilisation of an electronic ID card for the passenger's identification has been proposed. Pursuant to the amended act on identification cards, all inhabitants in the SR, including children under 15, shall hold such a card by the end of the year 2021. Electronic ID cards will be protected adequately with a safety code. The advantage of this proposal is the option to connect more electronic ID cards into one account in the back-office database (e.g., account of a legal representative). The implementation procedure would be the same as in the case of the first proposal, however, all 
members of the group would register their electronic ID cards in the back-office, and in the clearing centre there would be a bank account designed that would be used for sending the payment orders.

Author Contributions: Conceptualization, E.B. and B.B.; methodology, E.B.; data curation, E.B. and B.B.; investigation, E.B. and B.B.; formal analysis B.B. and E.N.; writing-original draft preparation, E.B., B.B., E.N.; visualization, E.B. and B.B.; project administration and funding acquisition, E.B. All authors have read and agreed to the published version of the manuscript.

Funding: This paper is a partial output of the grant project VEGA 1/0791/18: The Assessment of Economic and Technological Aspects in the Provision of Competitive Public Transport Services in Integrated Transport Systems.

Conflicts of Interest: The authors declare no conflict of interest.

\section{References}

1. Poliak, M.; Poliakova, A.; Mrnikova, M.; Šimurková, P.; Jaśkiewicz, M.; Jurecki, R. The competitiveness of public transport. J. Compet. 2017, 9, 81-97. [CrossRef]

2. Jánošíková, L'.; Slavík, J.; Koháni, M. Estimation of a route choice model for urban public transport using smart card data. Transp. Plan. Technol. 2014, 37, 638-648. [CrossRef]

3. Fürst, E.W.M.; Herold, D.M. Fare evasion and ticket forgery in public transport: Insights from Germany, Austria and Switzerland. Societies 2018, 8, 98. [CrossRef]

4. Štatistický úrad Slovenskej Republiky. Available online: https://www.datacube.statistics.sk (accessed on 9 March 2020).

5. Mikolaj, J.; Vančo, B. Ekonometria Pre Manažérov (Econometrics for managers), 3rd ed.; Faculty of Security Engineering: Žilina, Slovakia, 2014; pp. 122-123.

6. Dolinayova, A.; Cerna, L. The possibilities of increasing the economic efficiency of regional rail passenger transport-A case study in Slovakia. In Sustainable Rail Transport; Springer International Publishing: Cham, Switzerland, 2020; pp. 97-127.

7. Brumercikova, E.; Bukova, B. The regression and correlation analysis of carried persons by means of public passenger transport of the Slovak Republic. Transp. Res. Procedia 2019, 44, 61-68. [CrossRef]

8. Program Stability Slovenskej Republiky na Roky 2019 až 2022 (The Stability Program SR 2019-2022). Available online: https:/www.mfsr.sk/files/archiv/16/ProgramstabilitySlovenskanaroky2019-2022.pdf (accessed on 21 April 2020).

9. Konvergencia Ekonomiky SR k Vyspelým Ekonomikám - stav, Riziká a Scenáre (The Convergence of the Slovak Economy to Developed Economies). Available online: https://www.mfsr.sk/sk/financie/institutfinancnej-politiky/publikacie-ifp/ekonomicke-analyzy/13-konvergencia-ekonomiky-sr-k-vyspelymekonomikam-stav-rizika-scenare-august-2006.html (accessed on 20 April 2020).

10. Dolinayova, A.; Masek, J.; Kendra, M.; Camaj, J.; Grandsart, D.; Marlier, E.; Colzani, P.; Arena, M.; Paragreen, J.; Navaratnam, P.; et al. Research of the passenger's preferences and requirement for the travel companion application. J. Adv. Transp. 2018, 1-12. [CrossRef]

11. Drozdziel, P.; Rybicka, I.; Brumercikova, E.; Bukova, B. The application of the progressive decision-making methods in the electronic payment system in public transport. Transp. Probl. 2019, 14, 135-144. [CrossRef]

12. Brumercikova, E.; Bukova, B. Proposal for using the NFC technology in regional passenger transport in the Slovak Republic. Open Eng. 2020, 10, 238-244. [CrossRef]

13. Tibaut, A.; Kaučič, B.; Rebolj, D. A standardised approach for sustainable interoperability between public transport passenger information systems. Comput. Ind. 2012, 63, 788-798. [CrossRef]

14. Ferreira, M.C.; Nóvoa, H.; Dias, T.G.; Cunha, J.F. A proposal for a public transport ticketing solution based on customers' mobile devices. Procedia Soc. Behav. Sci. 2014, 111, 232-241. [CrossRef]

15. Stopka, O.; Zitricky, V.; Abramovic, B.; Marinov, M.; Ricci, S. Innovative technologies for sustainable passenger transport. J. Adv. Transp. 2019, 2. [CrossRef]

16. Populačný Vývoj v Krajoch a Okresoch Slovenska od Začiatku 21. Storočia (The Population Development in Regions and Districts of Slovakia Since the Beginning of the 21st Century). Available online: http: //www.infostat.sk/vdc/pdf/populacny_vyvoj_2019.pdf (accessed on 2 March 2020).

17. Stopka, O.; Bartuska, L.; Kampf, R. Passengers's evaluation of the integrated transport system. NAŠE MORE: Znan.-stručni časopis za More i Pomor. 2015, 62, 153-157. [CrossRef] 
18. Madlenak, R.; Dutkova, S.; Hostakova, H.; Sarkan, B. Reliability enhancement using optimization analysis. Zesz. Nauk. Transp./Politech. Ślaska 2018, 100, 115-125. [CrossRef]

19. Mankowski, C.; Weiland, D.; Abramovic, B. Impact of railway investment on regional development-Case study of Pomeranian metropolitan railway. Promet. Traffic. Transp. 2019, 31, 669-679. [CrossRef]

20. Khaled, Z.Z. Acount based ticketing: The benefits and drivers for transit operators. J. Transp. Technol. 2018, 8, 331-342.

21. Yap, M.D.; van Oort, N.; van Nes, R.; van Arem, B. Identification and quantification of link vulnerability in multi-level public transport networks: A passenger perspective. Transportation 2018, 45, 1161-1180. [CrossRef]

22. Rybicka, I.; Drozdziel, P.; Stopka, O.; Luptak, V. Methodology to propose a regional transport organization within specific integrated transport system: A case study. Transp. Probl. 2018, 18, 115-125. [CrossRef]

23. Mindur, M. The passenger transportation in America, Europe and Asia. Scientific. J. Sil. Univ. Technol. Ser. Transp. 2012, 75, 39-52.

24. Camacho, T.; Foth, M.; Rakotonirainy, A.; Rittenburch, M.; Bunker, J. The role of passenger-centric innovation in the future of public transport. Public Transp. 2016, 8, 453-475. [CrossRef]

(C) 2020 by the authors. Licensee MDPI, Basel, Switzerland. This article is an open access article distributed under the terms and conditions of the Creative Commons Attribution (CC BY) license (http://creativecommons.org/licenses/by/4.0/). 